\title{
Comparison of the Suitability of Contiguous Fallow-forest Lands for Cassava, Yam, Cocoyam and Sweet Potato Production in Nsukka, Southeastern Nigeria
}

\author{
Asadu Charles L. A. \\ University of Nigeria, Department of Soil Science, Nigeria
}

Dixon Alfred G. 0.

International Institute of Tropical Agriculture, Nigeria

Ajogu Ginika M.

University of Nigeria, Department of Soil Science, Nigeria

Ugadu Miriam

University of Nigeria, Department of Soil Science, Nigeria

\section{Edeh Ifeoma}

University of Nigeria, Department of Soil Science, Nigeria

\begin{abstract}
This analysis compared the suitability of contiguous fallow-forest lands for cassava, yam, cocoyam and sweet potato production in Nsukka, south-eastern Nigeria. The fallow plots were brought into cultivation in 1998 under the IITA-UNN long-term collaborative research. The sole cassava plots were grown to cassava only continuously for five years and then left to fallow. Soil samples were collected from $0-20 \mathrm{~cm}$ depth in triplicates using an auger and core sampler from the seven representative fallow plots previously grown to sole cassava from 1998-2003 and under fallow till date as well as the adjacent forest land. The objective was to use the soil qualities as recovered during the fallow period and those from the original adjacent forest to determine their current suitability for the production of the four crops. Using the FAO's principle of limiting conditions revealed that after 13 yrs of fallow, the plots grown to sole cassava was classified as highly suitable (S1) for sweet potato production but moderately suitable (S2) for cassava, yam and cocoyam production. The remnant forest land was highly suitable for sweet potato production but moderately suitable for cassava, yam and cocoyam production. The dominant soil limitations are organic matter, low cation exchange capacity and exchangeable potassium for both cassava and yam production. The major limitations to cocoyam production are low available phosphorous, base saturation and soil $\mathrm{pH}$. If these constraints are addressed adequately by soil nutrient management programmes all the plots will scale up to $\mathrm{S} 1$ class for the four crops.
\end{abstract}

Keywords: fallowing; nutrient sustainability; cassava; cocoyam; yam; sweet potato.

UDC 631.4

LCC Subject Category: SB1-1110

DOI: http://dx.doi.org/10.22178/pos.18-1

\section{Introduction}

Soil fertility depletion is a major problem in tropical Africa, resulting to decline in per capital food production as crop lands have a negative nutrient balance, due to crop harvest, leaching and low inputs applied to the soil [1,2,]. The fertility status of any soil deteriorate with changes in land use especially when the natural ecosys- 
tem (forest) is converted to crop land and continuous cultivation of such lands are involved [25]. This manifests as changes in soil properties such as nutrient content $(\mathrm{N}, \mathrm{P}, \mathrm{K}, \mathrm{Ca}, \mathrm{Mg}, \mathrm{S}$ etc), $\mathrm{pH}$, organic matter, CEC, structure etc $[9,6,10]$. Cropping a land without nutrient replenishment adversely affects the physico-chemical properties of the soil [18] which according to [16] contribute significantly to crop yield. Food crops grown on millions of hectares of soils all over the tropics no longer perform optimally well because most of the soils do not contain enough essential nutrients resulting in poor yields and subsequently the starvation of the people [41]. These yield reductions are mostly due to nutrient deficiencies resulting from decreases in soil organic matter content [42] and depletion of soil nutrients reserve during the cropping season. However, yield reductions are not only caused by poor nutrients status of the soils but also due to inappropriate land utilization types. Growing a crop on a land without due assessment of its suitability for such use, leads to suboptimal soil productivity and low yield as crop requirements are not often related to the land's potential capacity [26].

Fallowing is one method used in restoring the fertility status of degraded farmlands [17]. Its effect cannot be overemphasized in the improvement of agriculture because fallowing a soil gives it the potential to capture nutrients and make them available for crops; it reduces weeds, pest and disease infestations, restores soil organic matter and rehabilitates the population of soil organisms reduced during the cultivation period [50]. Long fallow period was found to increase the yield and protein content of wheat and its benefits extended beyond the next crop planted in the area. In the tropics, decision on land utilization types lies solely on the hands of the land owners who are mostly peasant farmers and not on the outcome of professional land evaluation, thus resulting to suboptimal land productivity and poor yield as land potential qualities are not often related to the crop growth requirements [26]. Therefore, assessment of soil physicochemical properties with respect to land utilization types is useful and paramount for sustainable agricultural productivity [49]. Generally, a sound understanding of land use effects on soil properties provides an opportunity to evaluate the sustainability of land use systems [53] and their suitability for a defined use so as to optimize and sustain agricultural productivity.
Cassava (Manihot spp.), yam (Dioscorea spp.), cocoyam (Colocasia esculenta) and sweet potato (Ipomoea batatas) belonging to the families of Enphorbianceae, Dioscoreae, Araceae and Solanaecae respectively, are the most important food crops grown in Nigeria as sources of food and carbohydrate. Cassava production in Nigeria is by far the largest in the world, producing $(\approx 52$ million tonnes per yr), almost $19 \%$ of total world production [31]. Nigeria accounts for about 71\% $(\approx 26$ million tonnes) of the total world production of yam as reported by [33]. Cocoyam is the fifth most harvested corn crop in the world with the production estimate of 9 million tonnes [33]. Nigeria is the world's largest producer of cocoyam with an estimated 4.55 million metric tonnes in 2012 with about $43.1 \%$ of the total production in Africa [33]. Globally, sweet potato ranked third after Irish potato and cassava in the world's root and tuber crops [37].

There is need for the assessment of changes in soil physicochemical properties which are associated with different land uses before drawing conclusion on the potential nutrients status of soils [7] and their suitability for a defined use so as to optimize and sustain agricultural productivity. Many studies have addressed the effects of fallowing and/ or continuous cultivation on soil physicochemical properties in Nsukka, Southeastern Nigeria [13, 14]. However, studies comparing the physicochemical properties of an alfisol under fallow and adjacent forest lands and their suitability for cocoyam, cassava, yam and sweet potato production in Nsukka, Southeastern Nigeria have not been fully examined. Therefore, this study (which is part of a long-term soil fertility management experiment established in 1998 at Amagu, Edem-Nru in Nsukka) compared the physicochemical properties of an alfisol under fallow and adjacent forest lands and their suitability for cocoyam, yam, cassava and sweet potato production in Nsukka, Southeastern Nigeria.

\section{Materials and methods}

Site Description. The study area was at Amagu Edem-Nru, in Nsukka, Enugu State. It lies within the latitude $6^{\circ} 52^{\prime} \mathrm{N}$ and longitude $7^{\circ} 23^{\prime} \mathrm{E}$ in the Savannah zone of Southeastern Nigeria with an elevation of $447.2 \mathrm{~m}$ above sea level [43]. The climate of the area is characterized by an average annual rainfall of about $1550 \mathrm{~mm}$ and average temperatures (minimum and maximum) of $22^{\circ} \mathrm{C}$ 
and $30{ }^{\circ} \mathrm{C}$ respectively while the average relative humidity is $60 \%$ [12]. Soils in this area are generally derived from the residua of False-bedded Sand-stone or Upper-coal Measure Formation as a result of disintegration of the rocks [10]. These geological formations give rise to the sandy and clayey soils respectively [10].The natural vegetation of Nsukka is characteristically derived Savannah agro-ecological zone with different land uses such as forestry, cultivated areas and grasslands in a soil-landscape system. Cassava, maize, yam, pigeon pea, egg plants, oil palm and pumpkins production is the dominant livelihood strategy of all members of the farming community.

Prof. Asadu et al. [17] reported that some part of a forest in Amagu Edem-Nru, in Nsukka, was cleared in January 1998 and partitioned into seven plots of $8 \mathrm{~m}$ by $5 \mathrm{~m}$ and each plot was replicated three times. Randomized Complete Block Design (RCBD) was used in establishing the trials. Seven treatments were applied: sole cassava (Manihot esculenta Crantz) (SC), sole pigeon pea (Cajanus cajan) (SP), sole maize (Zea mays) (SM), their combination $(\mathrm{M}+\mathrm{P}, \mathrm{C}+\mathrm{P}$ and $\mathrm{C}+\mathrm{M}+\mathrm{P})$ and $\mathrm{a}$ control plot based on the prior knowledge of the most common staple food crops grown by the local farmers. The crops were planted at a spacing of $1 \mathrm{~m} \times 1 \mathrm{~m}$ on ridges made with hoes. The land was continuously cropped for five years (1998-2003) and afterwards left to fallow till date. Presently, the fallow plots are covered predominantly with Siam weed (Chromolaena odorata), guinea grass (Panicum maximum) and elephant grass (Pennisetum purpureum). There are also some shrubs and oil palm (Elaiess guineensis) trees that have re-established since the fallowing began.

Soil Sampling and Laboratory Analysis. Following the previous studies, the seven fallow plots were sampled each in triplicates from the fallow land; triplicate samples were also collected from the adjacent forest giving a total of twenty-four (24) samples all from 0-20 cm soil depth using an auger and core sampler. Soil samples were air dried, crushed, passed through a $2 \mathrm{~mm}$ sieve and analyzed using standard procedure. Soil particle size distribution was determined by the Bouyoucos hydrometric method [52]. Bulk density was determined by the core method [19]. Pore size distribution was determined using the water retention data as follows: macroporosity from the volume of water drained at $60 \mathrm{~cm}$ of ten- sion/volume of bulk soil; microporosity from volume of water retained at $60 \mathrm{~cm}$ of tension/volume of bulk soil; and total porosity from the sum of macroporosity and microporosity [20]. Hydraulic conductivity was measured using Klute and Dirksen method [39].

Soil pH was measured in water and potassium chloride (1N KCL) suspension in a 1:2.5 (soil: liquid ratio) [46]. Available phosphorus (P) was extracted with Bray (II) solution. Organic carbon content was determined using Walkley-Black's titration method [38]. Total nitrogen (N) was determined using Kjeldahl digestion, distillation and titration method as described by [21]. Exchangeable $\mathrm{Na}$ and $\mathrm{K}$ were analyzed by Flame photometer [46] while exchangeable $\mathrm{Ca}$ and $\mathrm{Mg}$ were determined by titration method using $0.1 \mathrm{~N}$ EDTA [22]. Cation Exchange Capacity (CEC) was thereafter estimated titrimetrically using $0.1 \mathrm{~N}$ $\mathrm{NaOH}$ [22]. Exchangeable Acidity (EA) was determined as described by [22]. Percentage Base Saturation was calculated as (1):

$$
P B S=\frac{T E B}{E C E C} \times 100,
$$

where PBS - percentage base saturation; TEB - total exchangeable bases; ECEC - effective cation exchange capacity.

Land Suitability Evaluation. The suitability of the soils for the production of cassava, yam, cocoyam and sweet potato was assessed using the principle of limiting condition [28]. The soils were placed in suitability classes by matching their characteristics with the requirements of the crops and the overall suitability class of the soils was that indicated by its most limiting characteristics for the conventional approach [28]. The detailed land and soil requirements for each of the crops are presented in Tables 1-5.

\section{Results and discussions}

Physical Properties. The physical properties of the soil are shown in Table 6. Generally, both sand and clay fractions dominated over the silt fraction so that the order in magnitude is sand > clay $>$ silt. The low silt content may be due to its low values in the parent material of the soil [4]. 
Table 1: Land and Soil Requirement for Cassava [51]

\begin{tabular}{|l|c|c|c|c|c|}
\hline Land Qualities & $\begin{array}{c}100-85 \\
\text { (S1) }\end{array}$ & $\begin{array}{c}85-60 \\
(\mathrm{~S} 2)\end{array}$ & $\begin{array}{c}60-40 \\
(\mathrm{~S} 3)\end{array}$ & $\begin{array}{c}40-25 \\
(\mathrm{~N} 1)\end{array}$ & $\begin{array}{c}<25 \\
(\mathrm{~N} 2)\end{array}$ \\
\hline $\begin{array}{l}\text { Climate (c): } \\
\text { - MAR(mm) }\end{array}$ & $1000-1800 / 1800-2400$ & $750-600 />2400$ & $600-550$ & $550-500$ & $<500$ \\
\hline - MAT $\left.{ }^{\circ} \mathrm{C}\right)$ & $20-30 / 0-18$ & $>30 / 18-16$ & $16-14$ & $14-12$ & $<12$ \\
\hline - Soil texture & $\mathrm{L}, \mathrm{SCL}, \mathrm{CL}, \mathrm{SL}, \mathrm{SiCL}, \mathrm{SiC}$ & $\mathrm{Cs}, \mathrm{LFs}, \mathrm{LS}, \mathrm{LCS}, \mathrm{Fs}$ & $\mathrm{CS}, \mathrm{S}, \mathrm{Cs}$ & $\mathrm{SC}, \mathrm{Cm}$ & $\mathrm{Cm}, \mathrm{S}$ \\
\hline $\begin{array}{l}\text { Fertility f: } \\
\text { - CEC }(\mathrm{Cmol} / \mathrm{kg})\end{array}$ & $>16$ & $>10$ & & & \\
\hline - Base saturation (\%) & $>35$ & $35-15$ & $15-10$ & $<10$ & $<10$ \\
\hline - Organic matter (g/kg) & $>15$ & $>8$ & $>5$ & $<3$ & $<3$ \\
\hline
\end{tabular}

MAT: mean annual temperature; Cs: structural clay; Cm: massive clay; SiC: silty clay; SiCL: silty clay loam; CL: clay loam; Si: silt; L: loam; SCL: sandy clay loam; SL: sandy loam; LFs: loam fine sand; LCS: loam coarse sand; Fs: fine sand; S: sand

Table 2: Land and soil requirement for yam [51]

\begin{tabular}{|l|c|c|c|c|c|}
\hline Land Qualities & $100-85$ & $85-60$ & $60-40$ & $40-25$ & $<25$ \\
& S1 & S2 & S3 & N1 & N2 \\
\hline $\begin{array}{l}\text { Climate (c): } \\
\text { - MAR (mm) }\end{array}$ & $1000-750 / 1200-1600$ & $750-600$ & $600-550$ & $550-500$ & $<500$ \\
\hline - MAT (ㅇ) & $25-35$ & $20-25$ & $15-20$ & $<15$ & $<15$ \\
\hline - Soil texture & SL, SCL, CS, SiCL, CL, L, & Cs, LFs, LS, LCs & Cs, S & SC, Cm, & Cm, S \\
\hline $\begin{array}{l}\text { Fertility f: } \\
\text { - CEC (Cmol/kg) }\end{array}$ & $>16$ & $>10$ & & & \\
\hline - Base Saturation (\%) & $>35$ & $>15$ & $15-10$ & $<10$ & $<10$ \\
\hline - Organic Matter (g/kg) & $>15$ & $>8$ & $<5$ & $<3$ & $<3$ \\
\hline
\end{tabular}

Cs: structural clay; Cm: massive clay; SiCs: silty clay; SiCL: silty clay loam; CL: clay loam; Si: silt; L: loam; SCL: sandy clay loam; SL: sandy loam; LFs: loam fine sand; LCs: loam coarse sand; Fs: fine sand; S: sand

Table 3 - Land and soil requirement for cocoyam production [36]

\begin{tabular}{|l|c|c|c|c|}
\hline Land qualities & S1 & S2 & S3 & NI \\
\hline Temperature $\left({ }^{\circ} \mathrm{C}\right)$ & $21-27$ & $25-30$ & $30-35$ & $>35$ \\
\hline Total rainfall $(\mathrm{mm})$ & $\geq 2000$ & $1300-1999$ & $1000-1299$ & $<1000$ \\
\hline Base saturation $(\%)$ & $>60$ & $40-60$ & $20-39$ & $<20$ \\
\hline Soil pH & $>5-6.5$ & $4.5-5$ & $4-4.4$ & $<4.0$ \\
\hline
\end{tabular}

Table 4 - Land and soil requirement for sweet potato production [45]

\begin{tabular}{|l|c|c|c|c|}
\hline Land qualities & S1 & S2 & S3 & NI \\
\hline Temperature $\left({ }^{\circ} \mathrm{C}\right)$ & $16-25$ & $26-30$ & $31-32$ & $>32$ \\
\hline Total rainfall $(\mathrm{mm})$ & $\geq 1300$ & $800-1300$ & $500-800$ & $<500$ \\
\hline Base saturation $(\%)$ & $50-80$ & $45-50$ & $45-40$ & $<40$ \\
\hline Soil pH & $4.5-6.5$ & $6.6-8.2$ & $>8.2$ & $>8.2$ \\
\hline
\end{tabular}


Table 5 - Suitability Classes and their Description [27]

\begin{tabular}{|l|l|}
\hline Suitability Class & Description \\
\hline $\begin{array}{l}\text { Class S1: Highly } \\
\text { Suitable }\end{array}$ & $\begin{array}{l}\text { Land having no significant limitations to sustained application of a given use, or only } \\
\text { minor limitations that will not significantly reduce productivity or benefits and will } \\
\text { not raise inputs above an acceptable level. }\end{array}$ \\
\hline $\begin{array}{l}\text { Class S2: } \\
\text { Moderately } \\
\text { Suitable }\end{array}$ & $\begin{array}{l}\text { Land having limitations which in aggregate are moderately severe for sustained } \\
\text { application of a given use; the limitations will reduce productivity or benefits and } \\
\text { increase required inputs to the extent that the overall advantage to be gained from } \\
\text { the use, although still attractive, will be appreciably inferior to that expected on } \\
\text { Class S1 land. }\end{array}$ \\
\hline $\begin{array}{l}\text { Class S3: } \\
\text { Marginally } \\
\text { Suitable }\end{array}$ & $\begin{array}{l}\text { Land having limitations which in aggregate are severe for sustained application of a } \\
\text { given use and will so reduce productivity or benefits, or increase required inputs, } \\
\text { that this expenditure will be only marginally justified. }\end{array}$ \\
\hline $\begin{array}{l}\text { Class N: Currently } \\
\text { Not Suitable }\end{array}$ & $\begin{array}{l}\text { Land having limitations which may be surmountable in time but which cannot be } \\
\text { corrected with existing knowledge at currently acceptable cost; the limitations are } \\
\text { so severe as to preclude successful sustained use of the land in the given manner. }\end{array}$ \\
\hline $\begin{array}{l}\text { Class N2: } \\
\text { Permanently Not } \\
\text { Suitable }\end{array}$ & $\begin{array}{l}\text { Land having limitations which appear as severe as to preclude any possibilities of } \\
\text { successful sustained use of the land in the given manner. }\end{array}$ \\
\hline
\end{tabular}

The textural classes (sandy loam and sandy clay loam) are within the textures representative of the soils derived from false-bedded sand stone parent materials which occupy the lower slopes of Nsukka area in Nigeria $[10,13,14]$.

Table 6 - Selected physical properties

\begin{tabular}{|l|r|r|r|r|r|r|r|r|r|}
\hline Land use & Sand (g/kg) & Silt (g/kg) & Clay (g/kg) & TC & BD (kg/m3) & Map (\%) & Mip (\%) & Tp (\%) & Ks cm/hr \\
\hline pgSC & 728.50 & 72.80 & 198.70 & SL & 1350 & 9.15 & 48.74 & 57.89 & 64.60 \\
\hline pgC+M+P & 735.20 & 59.50 & 205.30 & SCL & 1310 & 7.95 & 48.27 & 56.22 & 68.00 \\
\hline pgC+P & 741.90 & 59.50 & 198.70 & SL & 1350 & 7.80 & 48.76 & 56.56 & 53.40 \\
\hline pgSM & 741.90 & 59.50 & 198.70 & SL & 1420 & 5.70 & 46.39 & 52.09 & 29.40 \\
\hline pgM+P & 755.20 & 39.50 & 205.30 & SCL & 1360 & 8.90 & 50.62 & 59.52 & 65.00 \\
\hline pgSP & 768.50 & 26.10 & 205.30 & SCL & 1390 & 7.49 & 48.62 & 56.11 & 25.80 \\
\hline EP & 748.50 & 72.80 & 178.70 & SL & 1270 & 6.72 & 47.61 & 54.33 & 70.40 \\
\hline Forest & 721.90 & 46.10 & 232.00 & SCL & 1280 & 9.46 & 49.44 & 58.90 & 125.00 \\
\hline
\end{tabular}

Note: $p g S C=$ previously grown to Sole Cassava; $p g C+M+P=$ previously grown to Cassava + Maize + pigeon pea pgM+P: previously grown to Maize and Pigeon pea; pgSP: previously grown to Sole Pigeon pea; $p g \mathrm{M}+\mathrm{P}=$ previously grown to Maize +pigeon pea; EP: Control Plot; TC: Textural Class; BD: Bulk Density; Map: Macroporosity; Mip: Microporosity; Tp: Total Porosity; Ks: Saturated hydraulic conductivity; SCL: Sandy Clay Loam.

The relatively low bulk density values recorded across both the fallow plots and forest (1270 $\mathrm{kg} / \mathrm{m} 3-1420 \mathrm{~kg} / \mathrm{m} 3$ ) is attributed to reduced or no cultivation activities as earlier found by [5]. Plant performs best if bulk densities are below $1400 \mathrm{~kg} / \mathrm{m} 3$ and $1600 \mathrm{~kg} / \mathrm{m} 3$ ) for clayey and sandy soils respectively [24].

Total porosity values ranged from $57.9 \%$ to $58.9 \%$ the values are within those described as good agricultural soils [34, 48]. The saturated hydraulic conductivity (Ks) obtained from the forest land was the highest value $(125.00 \mathrm{~cm} / \mathrm{hr})$.
Fallowing has been reported to be important in the improvement of both soil properties and saturated hydraulic conductivity of soils.

Chemical Properties. The chemical properties of the soil are shown in Table 7. The $\mathrm{pH}$ of the soil measured in water ranged from 4.27 to 4.33 , indicating an extreme acid reaction [40]. This may be due to the acidic nature of the parent material from which the soils were derived combined leaching of cations prevalent in the soils of the area which had earlier been reported $[11,13]$. 
Table 7 - Chemical properties of the soils

\begin{tabular}{|c|c|c|c|c|c|c|c|c|c|c|c|}
\hline \multirow{2}{*}{ Land use } & \multirow{2}{*}{$\mathrm{pH}$} & \multirow{2}{*}{$\mathrm{OC}(\mathrm{g} / \mathrm{kg})$} & \multirow{2}{*}{$\mathrm{TN}(\mathrm{g} / \mathrm{kg})$} & EA & $\mathrm{Ca} 2+$ & Mg2+ & $\mathrm{Na}+$ & $\mathrm{K}+$ & CEC & \multirow[t]{2}{*}{ BS (\%) } & \multirow[t]{2}{*}{ Av P (mg/kg) } \\
\hline & & & & \multicolumn{6}{|c|}{$\mathrm{cmol} / \mathrm{kg}$} & & \\
\hline pgSC & 33 & 9.80 & 0.98 & 4.80 & 3.73 & 1.20 & 0.02 & 0.12 & 13.20 & 52.20 & 3.73 \\
\hline $\mathrm{pgC}+\mathrm{M}+\mathrm{P}$ & 4.30 & 8.90 & 0.70 & 4.93 & 3.67 & 1.20 & 0.01 & 0.05 & 15.47 & 50.80 & 3.10 \\
\hline $\mathrm{pgC}+\mathrm{P}$ & 4.33 & 10.30 & 0.75 & 4.67 & 4.73 & 1.60 & 0.01 & 0.07 & 13.33 & 57.80 & 3.41 \\
\hline pgSM & .33 & 9.10 & 0.70 & 4.40 & 5.07 & 0.57 & 0.01 & 0.06 & 15.33 & 57.00 & 3.72 \\
\hline $\mathrm{pgM}+\mathrm{P}$ & 4.27 & 8.00 & 0.89 & 4.53 & 4.00 & 0.73 & 0.01 & 0.06 & 14.80 & 50.90 & 2.79 \\
\hline pgSP & 4.30 & 11.70 & 0.79 & 5.47 & 4.00 & 1.20 & 0.01 & 0.06 & 12.93 & 47.50 & 3.73 \\
\hline EP & 4.33 & 13.80 & 0.84 & 5.07 & 3.93 & 0.93 & 0.01 & 0.06 & 13.07 & 52.20 & 3.73 \\
\hline Forest & 4.30 & 12.60 & 0.84 & 5.07 & 3.27 & 0.67 & 0.01 & 0.12 & 12.47 & 45.30 & 4.04 \\
\hline
\end{tabular}

Note: $\mathrm{pgSC}=$ previously grown to Sole Cassava; $\mathrm{pgC}+\mathrm{M}+\mathrm{P}=$ previously grown to Cassava + Maize + pigeon pea pgM+P: previously grown to Maize and Pigeon pea; pgSP: previously grown to Sole Pigeon pea; $p g \mathrm{M}+\mathrm{P}=$ previously grown to Maize +pigeon pea; EP: Control Plot; TC: Textural Class; BD: Bulk Density; Map: Macroporosity; Mip: Microporosity; Tp: Total Porosity; Ks: Saturated hydraulic conductivity; SCL: Sandy Clay Loam.

OC: organic carbon; AvP: available phosphorus; TN: total nitrogen; EA: Exchangeable Acidity; CEC: Cation Exchange Capacity \%BS: Percentage Base Saturation; $\mathrm{H}^{+}$: exchangeable hydrogen; $\mathrm{Al}^{3+}$ :exchangeable aluminium; $\mathrm{Ca}^{2+}$ :exchangeable calcium; $\mathrm{Mg}^{2+}$ :exchangeable magnesium; $\mathrm{Na}^{+}$: exchangeable sodium; $\mathrm{K}^{+}$:exchangeable potassium.

Organic matter is generally very low in the soils according to [40] ratings $(>116 \mathrm{~g} / \mathrm{kg}$ very high, 58-116 g/kg high, 23- $58 \mathrm{~g} / \mathrm{kg}$ medium, 12$23 \mathrm{~g} / \mathrm{kg}$ low and $<12 \mathrm{~g} / \mathrm{kg}$ very low). The low organic matter content of the soils in the fallow plots could be due to rapid decomposition and mineralization of organic materials contributed by sparse vegetation and high temperatures.

The nitrogen contents in all the soils were low, ranging from 0.7 to $0.98 \mathrm{~g} / \mathrm{kg}$. Most crops require values $(18 \mathrm{~g} / \mathrm{kg} \mathrm{N})$ much higher than the values obtained [44]. The low nitrogen contents are associated with the low OM contents of the soils.

Exchangeable $\mathrm{Al}$ is generally detrimental to plants and as soil $\mathrm{pH}$ decreases, exchangeable acidity (EA) increases [23] so that soils with $\mathrm{pH}$ values below 5.2 are likely to exhibit the AL3+ problem. The low soil organic matter levels of the soils could also have contributed to the high EA values.

The range of values of exchangeable Na $0.01-$ $0.02 \mathrm{cmol} / \mathrm{kg}$ ) in all the soils indicate very low concentrations which are below the critical limit for sodicity [20]. Exchangeable $\mathrm{Ca}, \mathrm{Mg}$ and $\mathrm{K}$ were generally rated moderate, low and very low for all plots except for some of the fallow plots ( $\mathrm{SC}, \mathrm{C}+\mathrm{M}+\mathrm{P}, \mathrm{C}+\mathrm{P}, \mathrm{M}+\mathrm{P}, \mathrm{SP}$ and $\mathrm{EP}$ ) where $\mathrm{Ca} 2+$ was low. Low exchangeable bases have been attributed to leaching losses of these bases below the root zones for most crops (> $100 \mathrm{~cm}$ depth).
The dominant exchangeable cations in the soils tend to be mainly calcium and magnesium while low content of potassium and sodium appeared to be due to absence of minerals high in them in the parent material.

According to [40], the soils having CEC of $>25$ $\mathrm{cmol} / \mathrm{kg}, 15-25 \mathrm{cmol} / \mathrm{kg}, 5-15 \mathrm{cmol} / \mathrm{kg}$ and $<5$ $\mathrm{cmol} / \mathrm{kg}$ are classified as high, medium, low and very low respectively. Based on the above ratings, the CEC values of the soils are rated medium. M. Yakubu et al [54] opined that organic matter content of soils which normally influences the CEC is generally low and therefore the CEC values may not be attributed to the amount of organic matter but for most tropical soils the contribution of organic matter to CEC is often greater than $50 \%[10,15]$.

From the FAO report [29] soils with base saturation of $>50 \%$ are regarded as fertile soils while soils with less than $50 \%$ are not fertile soils. Based on this therefore, the soils are generally fertile except for SP and forest plots. The low base saturation experienced in the forest $(45.3 \%)$ could be attributed to leaching of soluble cations with water down the profile.

The available phosphorus was very low (2.79 $4.04 \mathrm{mg} / \mathrm{kg}$ ) and this may be due to phosphorus fixation and the acidic nature of the soil. 
Land Suitability Evaluation. The matching of the land qualities/characteristics in tables 6-7 with land and soil requirements for suitability rating for cassava, yam, cocoyam and sweet potatoes production (Table 1-4) resulted in the suitability classes shown in Tables 8-11.

Table 8 - Suitability Class Scores and Aggregate Suitability Classification of the Soils for Cassava Production

\begin{tabular}{|l|c|c|c|c|c|c|c|}
\hline Land use & MAR $(\mathrm{mm})$ & MAT $(-\mathrm{o})$ & Texture & CEC $(\mathrm{Cmol} / \mathrm{kg})$ & BS $(\%)$ & OM (g/kg OC) & ASC \\
\hline pgSC & S1 & S1 & S1 & S2 & S1 & S2 & S2 \\
\hline pgC+M+P & S1 & S1 & S1 & S2 & S1 & S2 & S2 \\
\hline pgC+P & S1 & S1 & S1 & S2 & S1 & S2 & S2 \\
\hline pgSM & S1 & S1 & S1 & S2 & S1 & S2 & S2 \\
\hline pgM+P & S1 & S1 & S1 & S2 & S1 & S2 & S2 \\
\hline pgSP & S1 & S1 & S1 & S2 & S2 & S2 & S2 \\
\hline EP & S1 & S1 & S1 & S2 & S2 & S2 & S2 \\
\hline Forest & S1 & S1 & S1 & S2 & S1 & S2 & S2 \\
\hline
\end{tabular}

Note: $p g S C=$ previously grown to Sole Cassava; $\mathrm{pgC}+\mathrm{M}+\mathrm{P}=$ previously grown to Cassava + Maize + pigeon pea pgM+P: previously grown to Maize and Pigeon pea; pgSP: previously grown to Sole Pigeon pea; $p g \mathrm{M}+\mathrm{P}=$ previously grown to Maize +pigeon pea; EP: Control Plot; TC: Textural Class; BD: Bulk Density; Map: Macroporosity; Mip: Microporosity; Tp: Total Porosity; Ks: Saturated hydraulic conductivity; SCL: Sandy Clay Loam.MAR: Annual Rainfall; MAT: Mean Annual Temperature; BS: Base Saturation; CEC: Cation Exchange Capacity; OM: Organic Matter; C: Carbon; ASC: Aggregate Suitability Class; S1: Highly suitable; S2: Moderately suitable; S3: Marginally suitable.

Table 9 - Suitability Class Scores and Aggregate Suitability Classification of the Soils for Yam Production

\begin{tabular}{|l|c|c|c|c|c|c|c|}
\hline Land use & MAR $(\mathrm{mm})$ & MAT $(-\mathrm{o})$ & Texture & CEC $(\mathrm{Cmol} / \mathrm{kg})$ & BS $(\%)$ & OM (g/kg OC) & ASC \\
\hline pgSC & S1 & S1 & S1 & S2 & S1 & S2 & S2 \\
\hline pgC+M+P & S1 & S1 & S1 & S2 & S1 & S2 & S2 \\
\hline pgC+P & S1 & S1 & S1 & S2 & S1 & S2 & S2 \\
\hline pgSM & S1 & S1 & S1 & S2 & S1 & S2 & S2 \\
\hline pgM+P & S1 & S1 & S1 & S2 & S1 & S2 & S2 \\
\hline pgSP & S1 & S1 & S1 & S2 & S1 & S2 & S2 \\
\hline EP & S1 & S1 & S1 & S2 & S1 & S2 & S2 \\
\hline Forest & S1 & S1 & S1 & S2 & S1 & S2 & S2 \\
\hline
\end{tabular}

Note: $p g S C=$ previously grown to Sole Cassava; $\mathrm{pgC}+\mathrm{M}+\mathrm{P}=$ previously grown to Cassava + Maize + pigeon pea pgM+P: previously grown to Maize and Pigeon pea; pgSP: previously grown to Sole Pigeon pea; $p g \mathrm{M}+\mathrm{P}=$ previously grown to Maize +pigeon pea; EP: Control Plot; TC: Textural Class; BD: Bulk Density; Map: Macroporosity; Mip: Microporosity; Tp: Total Porosity; Ks: Saturated hydraulic conductivity; SCL: Sandy Clay Loam.MAR: Annual Rainfall; MAT: Mean Annual Temperature; BS: Base Saturation; CEC: Cation Exchange Capacity; OM: Organic Matter; C: Carbon; ASC: Aggregate Suitability Class; S1: Highly suitable; S2: Moderately suitable; S3: Marginally suitable.

All the fallow plots and the forestland were classified as moderately suitable (S2) for yam and cocoyam production (Tables 8 and 9). Organic matter, CEC and exchangeable potassium are the dominant limitations.

Table 10 shows the suitability classes of the soils for the production of cocoyam. All the fallow plots previously grown to $\mathrm{SC}, \mathrm{C}+\mathrm{M}+\mathrm{P}, \mathrm{C}+\mathrm{P}, \mathrm{SM}$, $\mathrm{M}+\mathrm{P}, \mathrm{SP}$, and the remnant forestland (EP) were rated moderately suitable (S2). The major limitations to cocoyam production was low base saturation and soil $\mathrm{pH}$.

All the fallow plots ( $\mathrm{SC}, \mathrm{C}+\mathrm{M}+\mathrm{P}, \mathrm{C}+\mathrm{P}, \mathrm{SM}, \mathrm{M}+\mathrm{P}, \mathrm{SP}$, and EP) and forest plot were rated are highly suitable (S1) for sweet potato production. Aluminium toxicity, exchangeable potassium, base saturation, total nitrogen and organic matter were the identified dominant constraints. 
Table 10 - Suitability Class Scores and Aggregate Suitability Classification of the Soils for Cocoyam Production

\begin{tabular}{|l|c|c|c|c|c|}
\hline Land use & MAR $(\mathrm{mm})$ & MAT $\left({ }^{\circ} \mathrm{C}\right)$ & BS $(\%)$ & Soil pH & ASC \\
\hline pgSC & S2 & S1 & S2 & S3 & S2 \\
\hline pgC+M+P & S2 & S1 & S2 & S3 & S2 \\
\hline pgC+P & S2 & S1 & S2 & S3 & S2 \\
\hline pgSM & S2 & S1 & S2 & S3 & S2 \\
\hline pgM+P & S2 & S1 & S2 & S3 & S2 \\
\hline pgSP & S2 & S1 & S2 & S3 & S2 \\
\hline EP & S2 & S1 & S2 & S3 & S2 \\
\hline Forest & S2 & S1 & S2 & S3 & S2 \\
\hline
\end{tabular}

Note: $p g S C=$ previously grown to Sole Cassava; $\mathrm{pgC}+\mathrm{M}+\mathrm{P}=$ previously grown to Cassava + Maize + pigeon pea pgM+P: previously grown to Maize and Pigeon pea; pgSP: previously grown to Sole Pigeon pea; $p g \mathrm{M}+\mathrm{P}=$ previously grown to Maize +pigeon pea; EP: Control Plot; TC: Textural Class; BD: Bulk Density; Map: Macroporosity; Mip: Microporosity; Tp: Total Porosity; Ks: Saturated hydraulic conductivity; SCL: Sandy Clay Loam.; MAR: Annual Rainfall; MAT: Mean Annual Temperature; BS: Base Saturation; Soil pH; ASC: Aggregate Suitability Class; S1: Highly suitable; S2: Moderately suitable; S3: Marginally suitable.

Table 11 - Suitability Class Scores and Aggregate Suitability Classification of the Soils for Sweet Potato Production

\begin{tabular}{|l|c|c|c|c|c|}
\hline Land use & MAR $(\mathrm{mm})$ & MAT $\left(^{\circ} \mathrm{C}\right)$ & BS $(\%)$ & Soil pH & ASC \\
\hline pgSC & S1 & S2 & S1 & S1 & S1 \\
\hline pgC+M+P & S1 & S2 & S1 & S1 & S1 \\
\hline pgC+P & S1 & S2 & S1 & S1 & S1 \\
\hline pgSM & S1 & S2 & S1 & S1 & S1 \\
\hline pgM+P & S1 & S2 & S1 & S1 & S1 \\
\hline pgSP & S1 & S2 & S1 & S1 & S1 \\
\hline EP & S1 & S2 & S1 & S1 & S1 \\
\hline Forest & S1 & S1 & S2 & S1 \\
\hline
\end{tabular}

Note: pgSC= previously grown to Sole Cassava; $\mathrm{pgC}+\mathrm{M}+\mathrm{P}=$ previously grown to Cassava + Maize + pigeon pea pgM+P: previously grown to Maize and Pigeon pea; pgSP: previously grown to Sole Pigeon pea; $p g \mathrm{M}+\mathrm{P}=$ previously grown to Maize +pigeon pea; EP: Control Plot; TC: Textural Class; BD: Bulk Density; Map: Macroporosity; Mip: Microporosity; Tp: Total Porosity; Ks: Saturated hydraulic conductivity; SCL: Sandy Clay Loam.MAR: Annual Rainfall; MAT: Mean Annual Temperature; BS: Base Saturation; Soil pH; ASC: Aggregate Suitability Class; S1: Highly suitable; S2: Moderately suitable; S3: Marginally suitable.

Generally, the low pH values of the soils also pose a limitation to the production of the four crops (cassava, yam, cocoyam and sweet potato) and this can be mitigated by liming and by use of tolerant cultivars.

\section{Conclusion and recommendation}

The suitability assessment of Alfisols of Southeastern Nigeria for cassava, yam, cocoyam and sweet potato carried out in this study showed that the climatic characteristics such as mean annual temperature, mean annual rainfall and sunshine hours, and soil texture were generally op- timum for cassava, yam, cocoyam and sweet potatoes cultivation. However, based on the FAO's principle of limiting conditions only the plots previously grown to sole cassava and the remnant forestland were classified as highly suitable (S1) for sweet potato production All the plots were classified as moderately suitable for cassava, yam and cocoyam production with low soil $\mathrm{pH}, \mathrm{CEC}$ and base saturation as major constraints identified. To enhance the productivity levels of these lands for optimum cassava, yam, cocoyam and sweet potatoes production these constraints need to be adequately addressed through liming and nutrient application. 


\section{References}

1. Adesodun, J. K, Adeyemi, E. F., \& Oyegoke, C. O. (2007). Distribution of nutrient elements within water-stable aggregates of two tropical agro ecological soils under different land uses. Soil and Tillage Research, 92, 190-197. doi: 10.1016/j.still.2006.03.003

2. Ahmed, H. (2002). Assessment of Spatial Variability of Some Physicochemical Properties of Soils under Different Elevations and Land Use Systems in the Western Slopes of Mount Chilalo, Arsi (Master's thesis, Alemaya University). Ethiopia.

3. Akamigbo, F. O. R, \& Asadu, C. L. A. (2001). The influence of parent materials on the soils of Southeastern Nigeria. East African Agriculture and Forest Journal, 48, 81-91.

4. Akamigbo, F. O. R. (1984). The accuracy of field textures in a humid tropical environment. Soil Survey and Land Evaluation, 4, 63-70.

5. Akamigbo, F. O. R. (1999). Influence of land use on soil properties of the humid tropical agroecology of Southeastern Nigeria. Nigerian Agriculture Journal, Vol. 30, 59-76.

6. Akinrinde, E. A., \& Obigbesan, G. O. (2000). Evaluation of fertility status of selected soils for crop production in five ecological areas of Nigeria. In 26th Annual Conference Soil Science (pp. 279288). Ibadan: n. d.

7. Alexandra, M., Charles, R., Jeangros, B., \& Sinaj, S. (2013). Effect of organic fertilizers and reducedtillage on soil properties, crop nitrogen response and crop yield: Results of a 12-year experiment in Changins, Switzerland. Soil and Tillage Research, 126, 11-18. doi: 10.1016/j.still.2012.07.012

8. Allen, V. B., \& Pilbeam, D. J. (Eds.). (2007). Handbook of Plant Nutrition. NW: CRC Press.

9. Aluko, A. P., \& Fagbenro, J. A. (2000). The role of tree species and land use systems in organic matter and nutrient availability in degraded Ultisol of Onne, Southeastern Nigeria. In 26th Annual Conference Soil Science (pp. 220-236). Ibadan: n. d.

10. Asadu, C. L. A., \& Akamigbo, F. O. R. (1990). Relative contributions of organic matter and clay fractions to cation-exchange capacity (CEC) of soils in Southeastern Nigeria. Samaru: Journal of Agriculture Research, 7, 17-23.

11. Asadu, C. L. A., Nwafor, I. A., \& Chibuike, G. U. (2015). Contributions of microorganisms to soil fertility in adjacent forest, fallow and cultivated land use types in Nsukka, Nigeria. International Journal Agriculture \& Forestry, 5(3), 199-204. Retrieved from http://article.sapub.org/10.5923.j.ijaf.20150503.04.html

12. Asadu, C. L. A, Obasi, S. C., \& Dixon A. G. O. (2010). Variations in soil physical properties in a cleared forestland continuously cultivated for seven years in eastern Nsukka, Nigeria. Communications in Soil Science and Plant Analysis, 41(2), 123-132. doi: 10.1080/00103620903426931

13. Asadu, C. L. A. (1990). A Comparative characterization of two foot-slope soils in Nsukka area of Eastern Nigeria. Soil Science, 150, 527-534.

14. Asadu, C. L. A., \& Ekeleman, L. D. (2014). The effects of continuous cropping and fallowing on the chemical properties of an ultisol in Nsukka, Nigeria. Agro-Science, 12(2), 1-28. doi: 10.4314/as.v12i2.4

15. Asadu, C. L. A., Diels, J., \& Vanluawe, B. (1997). A comparison of the contributions of clay, silt and organic matter to the effective CEC of soils in sub-Saharan Africa. Soil Science, 162, 785-794. doi: 10.1097/00010694-199711000-00003

16. Asadu, C. L. A., Dixon, A. G. O., \& Okechukwu, R. (2002). Comparative evaluation of the contribution of soil physicochemical properties to variations in the yield of four major staple food crops in eastern Nigeria. Soil Tillage Research, 65, 141-155. doi: 10.1016/s0167-1987(01)00276-8

17. Asadu, C. L. A., Obasi, S. C., Dixon, A. G. O., Ugele, N., \& Chibuike, G. U. (2013). Soil fertility recovery in cleared forestland cultivated and fallowed for seven years. Journal of Agriculture and Biodiversity Research, 2(5), 110-116. Retrieved from http://onlineresearchjournals.org/JABR/pdf/2013/jul/Asadu\%20et\%20al..pdf

18. Awotoye, O. O., Ogunkunle, C. O., \& Adeniyi, S. A. (2011). Assessment of soil quality under various land use practices in a humid agro-ecological zone of Nigeria. African Journal of Plant Science, 5(10), 565-569. Retrieved from http://www.academicjournals.org/article/article1380095760_Awotoye\%20et\%20al.pdf 
19. Blake, G. R., \& Hartge, K. H. (1965). Bulk density . In C. A. Black (Ed.), Methods of Soil Analysis (Part 1, Physical and mineralogical properties, including statistics of measurement and sampling, pp.363-382). Madison: American Society of Agronomy, Crop Science Society of America : Soil Science Society of America.

20. Brady, N. C., \& Weil, R. R. (2010). Elements of the nature and properties of soils. N. J.: Pearson Prentice Hall.

21. Bremner, J. M. (1965). Inorganic forms of nitrogen. Agronomy, 9, 1179-1237.

22. Chapman, H. D. (1965). Cation exchange capacity. In C. A. Black (Ed.), Methods of Soil Analysis (Part 1, Physical and mineralogical properties, including statistics of measurement and sampling, pp. 891-901). Madison: American Society of Agronomy, Crop Science Society of America : Soil Science Society of America.

23. Cronan, C. S., \& Grigal, D. F. (1995). Use of Calcium/Aluminum Ratios as Indicators of Stress in Forest Ecosystems. Journal of Environmental Quality, 24(2), 209. doi: 10.2134/jeq1995.00472425002400020002x

24. Donahue, R. L, Miller, R. W., Schickluna, J. C. (1977). Soils: An introduction to soils and plant growth. N. J.: Prentice-Hall.

25. Ezeaku, P. I., Alaci, D. (2008). Analytical situations of land degradation and sustainable management strategies in Africa. Journal of Agriculture \& Social Science, 4, 42-52.

26. Ezeaku, P. I., (2011). Sustainable Soil Management and Productivity. Nsukka: Great AP Express Publishers ltd.

27. Food and Agricultural Organization of the United Nation. (1976). A Framework for Land Evaluation. Retrieved from http://www.fao.org/docrep/X5310E/x5310e00.htm

28. Food and Agricultural Organization of the United Nation. (1995). Guidelines for Land Evaluation for Rainfall Agriculture. Retrieved from http://www.fao.org/docrep/003/x6083f/x6083f00.htm

29. Food and Agricultural Organization of the United Nation. (2014). World Reference Base for Soil Resources. Retrieved from http://www.fao.org/3/a-i3794e.pdf

30. Food and Agricultural Organization of the United Nation. (2006). Guidelines for Soil Description (4th ed.). Retrieved from http://www.fao.org/docrep/019/a0541e/a0541e.pdf

31. Food and Agricultural Organization of the United Nation. (2013). FAO STAT. Retrieved July 7, 2016, from http://faostat3.fao.org/home/index.html\#DOWNLOAD.

32. Food and Agricultural Organization of the United Nation. (2002). Land and agriculture: A Compendium of recent sustainable development initiatives in the field of agriculture and land management. Retrieved from ftp://ftp.fao.org/agl/agll/docs/landandagric.pdf

33. Food and Agricultural Organization of the United Nation. (2012). FAOSTAT Nigeria. Retrieved March 18, 2016, from http://www.fao.org/faostat/en/\#country/159

34. Fetter, C. W. (1994). Applied Hydrogeology. London: Prentice-Hall.

35. Gee, G. W., \& Bauder, J. W. (1965). Particle-size analysis. In C. A. Black (Ed.), Methods of Soil Analysis (Part 1, Physical and mineralogical properties, including statistics of measurement and sampling, pp. 383). Madison: American Society of Agronomy, Crop Science Society of America : Soil Science Society of America.

36. The Humanity Development Library. (2016). Tonnia (Xanthosoma spp.) and Taro (Colocasia esculenta). Retrieved from https://goo.gl/YGr8L9

37. Ikeorgu J. E. G. (2003). Effect of size and spacing of minitubers on yield of three selected yam cultivars in the humid tropics of Nigeria. Nigerian Agricultural Journal, 34, 58-62. doi: 10.4314/naj.v34i1.3170

38. Jackson, M. L. (1958). Soil chemistry analysis. London: London Constable.

39. Klute, A., \& Dirksen, C. (1965). Hydraulic conductivity and diffusivity. In C. A. Black (Ed.), Methods of Soil Analysis (Part 1, Physical and mineralogical properties, including statistics of measurement and sampling, pp. 694-783). Madison: American Society of Agronomy, Crop Science Society of America : Soil Science Society of America.

40. Landon, J. R. (Ed.). (1984). Booker tropical soil manual: A Handbook for Soil Survey and Agricultural Land Evaluation in the Tropics and Subtropics. London: Booker Agriculture International.

41. Marler, J. B., \& Wallin, J. R. (2006). Human health, the nutritional quality of harvested food and sustainable farming. Bellevue: Nutrition Security Institute. Retrieved from 
http://www.nutritionsecurity.org/PDF/NSI_White\%20Paper_Web.pdf

42. Oguike P. C., Mbagwu, J. S. C. (2009). Variations in some physical properties and organic matter content of soils of coastal plain sand under different land use types. World Journal of Agricultural Science, 5(1), 63-69. Retrieved from https://www.idosi.org/wjas/wjas5(1)/9.pdf

43. Oko-ibom, G. O., Asiegbu, J. E., (2006). Growth and yield responses of rainy season field tomatoes to timing and splitting of fertilizer application. Journal of Agriculture, Food, Environment and Extension, 5(1), 17-25. doi: 10.4314/as.v5i1.1540

44. Omotoso, T. I. (1973). Factors guiding the determination of phosphorus fertilizer requirements of cocoa growing soils in Western Nigeria. Retrieved from https://goo.gl/2602XI

45. Reddy, R. S., Shiva Prasad, C. R. (1999). Characterization and evaluation of potato growing soils of Karnataka. Journal of the Indian Society of Soil Science, 47, 525-532.

46. Rhoades, J. D. (1982). Cation Exchange Capacity. In: A. Page (Ed.), Methods of Soil Analysis (Part 2, Chemical and microbiological properties, 2nd ed., pp.149-157). Madison: American Society of Agronomy, Crop Science Society of America : Soil Science Society of America.

47. Rhoades, J. D. (1996). Salinity: Electrical conductivity and total dissolved solids. In. D. L. Sparks et al. (Eds.), Methods of Soil Analysis: Chemical Methods (Part 3, pp. 417-435). Madison: ASA, SSSA.

48. Riue, M., Sposito, G. (1991). Fractal fragmentation, soil porosity, and soil water properties: I. Theory. Soil Science Society of America Journal, 55, 1231-1238. doi: 10.2136/sssaj1991.03615995005500050006x

49. Selassie. Y, Anemut and Addisus (2015). The effects of land use types, management practices and slope classes on selected soil physico-chemical properties in Zikre watershed, North-Western Ethiopia. Environmental Systems Research, 4(1). doi: 10.1186/s40068-015-0027-0

50. Styger, E., \& Fernandes, E. C. M. (2006). Contributions of managed fallows to soil fertility recovery. In N. Th. Uphoff (Ed.), Biological Approaches to Sustainable Soil Systems (pp. 425-437). Boca Raton: CRC/Taylor\&Francis.

51. Sys, C. (1985). Land Evaluation. Brussel: Algemeen Bestuur van de Ontwikkelingssamenwerking.

52. Van Reeuwijk, L. P. (1992). Procedures for soil analysis (, 3rd ed.). Wageningen: International Soil Reference and Information Center.

53. Stroosnijder, L., Sterk, G., \& Bewket, W. (2003). Towards Integrated Watershed Management in High land Ethiopia: the Chemoga watershed case study (Doctoral thesis). Retrieved from https://goo.gl/8ZXDOQ

54. Yakubu, M., Baraya, S., \& Noma, S. S. (2007). Assessment of soil and water quality along river Kadarko in Sanyinna District, Sokoto State. In W. A. Hassan et al. (Eds.), Mobilizing agricultural research towards attaining food security and Industrial growth in Nigeria. Proceedings of the 45th Annual Conference of the Agriculture Society of Nigeria.

(C) C. L. A. Asadu, A. G. O. Dixon, G. M. Ajogu, M. Ugadu, I. Edeh 


\title{
Сравнение пригодности смежных лесных участков, вспаханных под пар, для выращивания культур маниока, батат, кокосового ямса и сладкого картофеля в провинции Nsukka, юго-восточная Нигерия
}

\author{
Asadu Charles L. A. \\ University of Nigeria, Department of Soil Science, Nigeria \\ Dixon Alfred G. 0. \\ International Institute of Tropical Agriculture, Nigeria \\ Ajogu Ginika M. \\ University of Nigeria, Department of Soil Science, Nigeria \\ Ugadu Miriam \\ University of Nigeria, Department of Soil Science, Nigeria \\ Edeh Ifeoma \\ University of Nigeria, Department of Soil Science, Nigeria
}

\begin{abstract}
Аннотация. Данное исследование сравнивало пригодность смежных возделанных лесных участков для выращивания маниоки, батата, кокосового ямса и сладкого картофеля в провинции Nsukka, юговосточная Нигерия. Болотные участки были культивированы в 1998 году в рамках долгосрочного совместного исследования IITA-UNN. Участки использовались только для выращивания маниоки в течение пяти лет, а затем их оставляли под паром. Образцы почвы были собраны с глубины 0-20 см в трех экземплярах с использованием бура и керноотборника на семи возделанных участках-образцах, ранее используемых для выращивания только маниоки в 1998-2003 и находящихся под паром до настоящего времени, а также на прилегающих лесных участках. Цель состояла в том, чтобы исследовать свойства почвы данных участков восстанавливаться в период нахождения по паром, а также свойства почвы прилегающих лесных участков с целью определения их пригодности для текущего производства четырех культур.
\end{abstract}

Использование принципа FAO предельных условий показало, что после 13 лет парования, участки, используемые для выращивания только маниоки, классифицировались как очень подходящие (S1) для выращивания сладкого картофеля, но умеренно подходящие (S2) для маниоки, батата и кокосового ямса. Остальные лесные угодья очень хорошо подходили для выращивания сладкого картофеля, но умеренно подходили для выращивания маниоки, батата, кокосового ямса. Доминирующими ограничениями почвы являются органические вещества, низкая емкость катионного обмена и обменный калий, как для выращивания маниоки, так и батата. Основными ограничениями для производства кокосового ямса являются низкое содержание фосфора, насыщенность почвы и уровень рН почвы. Если эти ограничения надлежащим образом учитываются программами обработки почвы питательными веществами, все участки будут масштабироваться до класса S1 для четырех культур.

Ключевые слова: пар; питательная устойчивость; маниока; кокосовый ямс; сладкий картофель.

УдК 631.4

LCC Subject Category: SB1-1110

DOI: http://dx.doi.org/10.22178/pos.18-1

(C) C. L. A. Asadu, A. G. O. Dixon, G. M. Ajogu, , M. Ugadu, I. Edeh

Статья получена 06.12.2016, принята 22.01.2017, опубликована оnline 26.01.2017 